\title{
Optics and remote sensing of Bahamian carbonate sediment whitings and potential relationship to wind-driven Langmuir circulation
}

\author{
H. M. Dierssen ${ }^{1}$, R. C. Zimmerman ${ }^{2}$, and D. J. Burdige ${ }^{2}$ \\ ${ }^{1}$ Department of Marine Sciences and Geography, Univ. of Connecticut, 1080 Shennecossett Road, Groton, CT 06340, USA \\ ${ }^{2}$ Department of Ocean, Earth \& Atmospheric Sciences, Old Dominion Univ., 4600 Elkhorn Ave., Norfolk, VA 23529, USA
}

Received: 30 September 2008 - Published in Biogeosciences Discuss.: 8 December 2008

Revised: 10 February 2009 - Accepted: 5 March 2009 - Published: 31 March 2009

\begin{abstract}
Regions of milky white seas or "whitings" periodically occur to the west of Andros Island along the Great Bahama Bank where the bottom sediment consists of finegrained aragonite mud. We present measurements of inherent optical properties within a sediment whiting patch and discuss the potential for monitoring the frequency, extent, and quantity of suspended matter from ocean colour satellite imagery. Sea spectral reflectance measured in situ and remotely from space revealed highly reflective waters elevated across the visible spectrum (i.e., "whitened") with a peak at $490 \mathrm{~nm}$. Particulate backscattering was an order of magnitude higher than that measured at other stations throughout the region. The whiting also had one of the highest backscattering ratios measured in natural waters $(0.05-0.06)$ consistent with water dominated by aragonite particles with a high index of refraction. Regular periodicity of 40 and $212 \mathrm{~s} \mathrm{ev}-$ ident in the light attenuation coefficient over the sampling period indicated patches of fluctuating turbidity on spatial scales that could be produced from regular rows of Langmuir cells penetrating the $5-\mathrm{m}$ water column. We suggest that previously described mechanisms for sediment resuspension in whitings, such as tidal bursting and fish activity, are not fully consistent with these data and propose that wind-driven Langmuir cells reaching the full-depth of the water column may represent a plausible mechanism for sediment resuspension and subsequent whiting formation. Optics and remote sensing provide important tools for quantifying the linkages between physical and biogeochemical processes in these dynamic shallow water ecosystems.
\end{abstract}

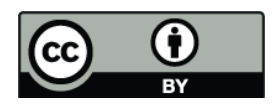

Correspondence to: H. M. Dierssen (heidi.dierssen@uconn.edu)

\section{Introduction}

The Bahama Banks represent an extensive carbonate depositional system that rises sharply from the deep western tropical Atlantic seafloor to a broad shallow platform whose water depth ranges from $4-8 \mathrm{~m}$. The tidal range of $\sim 1 \mathrm{~m}$ along these banks is markedly influenced by the strong winds common to this region. The region west of Andros Island on the Great Bahama Bank has relatively low wave-energy and is dominated by fine lime mud and pellet mud sediments (Purdy, 1963). The seas overlying these muds are well known for episodic, highly turbid events that produce milkywhite coloured waters, historically referred to as "whitings" (Cloud, 1962). Whitings cover from tens to hundreds of $\mathrm{km}^{2}$ and have an average suspended sediment concentration of $10 \mathrm{mg} \mathrm{L}^{-1}$ (Shinn et al., 1989). These whitings are so distinct that the dramatic white waters have been observed and enumerated from photography taken by astronauts aboard the Space Shuttle (Robbins et al., 1997). However, little is known about the inherent and apparent optical properties of the particles within whitings and the mechanism forming these whiting events still remains to be identified (Broecker, 2009).

The presence of milky seas or "whitings" in marine and freshwaters can stem from a variety of causes such as blooms of coccolithophores (Balch et al., 1991) or cyanobacterial picoplankton (Ohlendorf and Sturm, 2001), sulphur precipitates (Amend et al., 2004), resuspension of sediment in association with bottom-feeding or benthic fish (Sheffer et al., 2003), glacial "flour" in meltwater plumes (Dierssen et al., 2002), or even night-time bioluminescence (Miller et al., 2005). However, the source of Bahamian whiting events has been controversial and debated extensively in the scientific literature. Some have suggested that Bahamian whitings are

Published by Copernicus Publications on behalf of the European Geosciences Union. 
spontaneous precipitates of aragonite (Smith, 1940; Cloud, 1962) while others contend that whitings are resuspended sediment (Broecker et al., 2000; Bustos-Serrano et al., 2009). Over 70 years ago, Smith (1940) suggested that supersaturated water flowing onto the bank from the adjacent open ocean encountered condensation nuclei provided by resuspension of sediment and spontaneously precipitated calcium carbonate. Carbonate precipitation can also occur via microbial calcification and some have proposed that picoplankton may act as nucleation sites for epicellular carbonate precipitation in this region (Robbins and Blackwelder, 1992). To date, chemical measurements of alkalinity, $\mathrm{pH}$, and carbon isotopic data show no direct evidence of spontaneous (homogeneous) precipitation within whitings and a wide range of geochemical evidence suggests that whitings largely contain resuspended sediment (Broecker and Takahashi, 1966; Morse et al., 2003). However, a significant amount of carbonate precipitation, for example through precipitation onto suspended sediment (Morse et al., 2003) or algal particles (Robbins and Blackwelder, 1992), must occur along the Banks to account for the vast amount of aragonite mud lost in the deep seafloor of the Atlantic from large storms (Ball et al., 1967; Shinn et al., 1993; Wilber et al., 1990).

No plausible and consistent mechanism has been put forth to describe the forces responsible for sediment resuspension in whitings (e.g., see discussion in Broecker et al., 2000). Measured current velocities within whiting areas tend to be well below those required to erode and suspend bottom sediment, and are often of similar magnitude to those in adjacent regions outside the whiting areas (Shinn, et al., 1989). Boss and Neumann (1993) propose that whitings may be the result of the "bursting" cycle of turbulent tidal flow, but this mechanism has not been directly proven (Morse et al., 2003). Moreover, resuspension mechanisms involving tidal forcing are not consistent with the observed seasonal patterns of whitings (Robbins et al., 1997). The possibility that resuspension is caused by fish activity has also been proposed in the literature (Broecker et al., 2000). However, from sidescan sonar and fathometer imaging, trawls, remote video and scuba observations coupled with 25 years of casual observation, Shinn et al. (1989) contend that fish are not involved in the formation of most Bahamian whitings.

Here, we present measurements of inherent optical properties within a sediment whiting patch and propose that winddriven Langmuir cells (Langmuir, 1938) reaching the fulldepth of the water column (i.e., "Supercells", Garget et al., 2004) may represent a plausible mechanism for sediment resuspension and subsequent whiting formation. Langmuir cells at scales of $2 \mathrm{~m}$ to $1 \mathrm{~km}$ are now generally accepted to be the result of the interaction of the Stokes drift induced by surface waves and the vertical shear in turbulent fluid (Thorpe, 2004). Langmuir circulation is commonly characterized by three-dimensional rotating cells that form surface convergence at the boundary of counter-rotating cells (Weller et al., 1985) that can be visibly observed as windrows of buoyant material including algae, plankton, or bubbles aligned parallel to the winds (Monahan and Lu, 1990). However, a cell is neither steady nor uniformly spaced, but rather interacts with itself and other cells (Tejada-Martinez and Grosch, 2007).

While much research has focused on upper-ocean mixing, Langmuir circulation has only recently been recognized as a possible mechanism shaping seafloor processes. In shallow water, the vertical scale of Langmuir "supercells" can reach the full depth of the water column (Faller, 1971; Gargett, et al., 2004); thereby, potentially resuspending sediment, altering benthic constituents, and sculpting the seafloor. Along the eastern arm of the Bahama Banks, we observed Langmuir cells manifested as organized windrows of benthic macroalgae Colpomenia sp. that may have transported significant biomass off the shelf into deep water (Dierssen et al., 2009). The downward velocities of such supercells exceed the upward velocities $\left(>6 \mathrm{~cm} \mathrm{~s}^{-1}\right)$ and peak several meters below the sea surface. Sediment transport due to Langmuir supercells is distinct from that associated with surface waves because of the different vertical length scales. Near-bottom turbulence due to surface waves causes sediment resuspension only within a thin wave boundary layer extending tens of centimetres from the seafloor (Gargett et al., 2004; Grant, 1986). In contrast, Langmuir supercells create a mechanism whereby sediment can be moved out of the slow near-bottom flow and mixed throughout the water column. Hence, Langmuir circulation can play a dominant role in sediment dynamics in shallow environments, such as proposed here.

\section{Methods}

This study was conducted on the Bahama Banks in March 2004 aboard the $R / V$ Walton Smith (Fig. 1). An ac-9 Plus package (WET Labs, Inc.) was deployed at each station in a mooring mode which sampled for $6 \mathrm{~min}$ at a fixed depth of 2 $3 \mathrm{~m}$ below the sea surface. The instrument package was not profiled over the $\sim 5 \mathrm{~m}$ water column. Salinity and temperature were measured using an SBE 19 (Sea-Bird Electronics) integrated into the package. The particulate+dissolved absorption and attenuation coefficients, $a_{p g}$ and $c_{p g}$, were corrected for temperature and salinity (Sullivan et al., 2005) and scattering effects (Zaneveld et al., 1994). The proportional correction method was used for the whitings station. For some stations in the Bahamas, the proportional method was inaccurate and the baseline subtraction was employed. Drift offsets were obtained from a post-cruise clean water calibration. Total particulate scattering $\left(b_{p}\right)$ was calculated as the difference between $c_{p g}$ and $a_{p g}$, assuming that scattering from dissolved material was negligible. The particulate backscattering coefficient $\left(b_{b p}\right)$ refers to all the photons that have been redirected in the backward direction due to scattering from particles in the water and to a first order positively corresponds to the total concentration of particles in the water (reviewed in Stramski et al., 2004). The ECO-VSF (WET 
Labs) provided backscattering measurements at three angles $\left(100^{\circ}, 125^{\circ}\right.$, and $\left.150^{\circ}\right)$ and three wavelengths $(470,532$, and $650 \mathrm{~nm})$. There data were corrected for light attenuation effects using concurrent $a c-9$ data and extrapolated from 90$180^{\circ}$ using a third-order polynomial (Sullivan et al., 2005). The backscattering ratio $\left(\tilde{b}_{b p}\right)$ is the ratio of backward particulate scattering $\left(b_{b p}\right)$ to total particulate scattering $\left(b_{p}\right)$. The amount of suspended sediment, often referred to as "turbidity," was assessed both with measurements of particulate light attenuation and $\tilde{b}_{b p}$.

Chlorophyll (Chl)- $a$ concentrations were estimated by use of absorption measurements from the $a c-9$ by dividing the chlorophyll absorption peak height at $676 \mathrm{~nm}$ (using a baseline subtraction from $650 \mathrm{~nm}$ ) by a nominal specific absorption coefficient of $0.014 \mathrm{~m}^{2} \mathrm{mg}^{-1}$ following the methods of Sullivan et al. (2005). We note that this approach is only meant to provide an indicator of chlorophyll concentrations.

Above-surface radiance measurements were taken with the Field Spec Pro ${ }^{\text {TM }}$ VNIR-NIR1 portable spectrometer system from Analytical Spectral Devices. A sequence of measurements was made with an $8^{\circ}$ foreoptic focused at a 40 45 degree angle sequentially on a gray plaque, sea surface, and diffuse sky. The reflectivity of the gray plaque (Kodak gray card) was measured in the lab using the ASD and an integrating sphere $(\sim 15.6 \%)$. The measurements were used to derive an estimate of spectral remote sensing reflectance, $R_{r s}(\lambda)$, the ratio of water-leaving radiance normalized to the plane irradiance incident on the sea surface. Fresnel reflectance for a $40-45^{\circ}$ angle of observation of 0.028 was used (Kirk, 1994). Residual reflected sky radiance was corrected using the approach presented in Gould et al. (2001) using reflectance differences between 715 and $735 \mathrm{~nm}$, an approach specifically developed for coastal waters.

High resolution $(1 \mathrm{~km})$ Moderate Resolution Imaging Spectroradiometer (MODIS) Aqua Level 1A Local Area Coverage (LAC) images were downloaded from the National Aeronautics and Space Administration (NASA) for days coinciding with the field study. Clear sky images were available on $6,16,18,22,27$, and 30 March 2004. The whiting was encountered in the field on 28 March 2004 and compared to imagery collected one day prior (27 March 2004). Images were georeferenced and warped based on a complete geometry model of the earth and satellite orbit. Remote sensing reflectance was derived from MODIS imagery at $1 \mathrm{~km}$ resolution across the Bahama Banks. Since standard atmospheric correction routines are not designed for optically shallow water, we applied an iterative scheme to first process the image using the multiple-scattering atmospheric correction algorithm (Gordon, 1997). The atmospheric correction scheme from neighbouring deep water was identified and the entire image was then reprocessed with SeaDAS using a fixed aerosol optical depth representative of the region. This type of atmospheric correction is only an approximation of the atmospheric properties over shallow water and can lead to consistent biases in retrieved reflectances. In order to account for
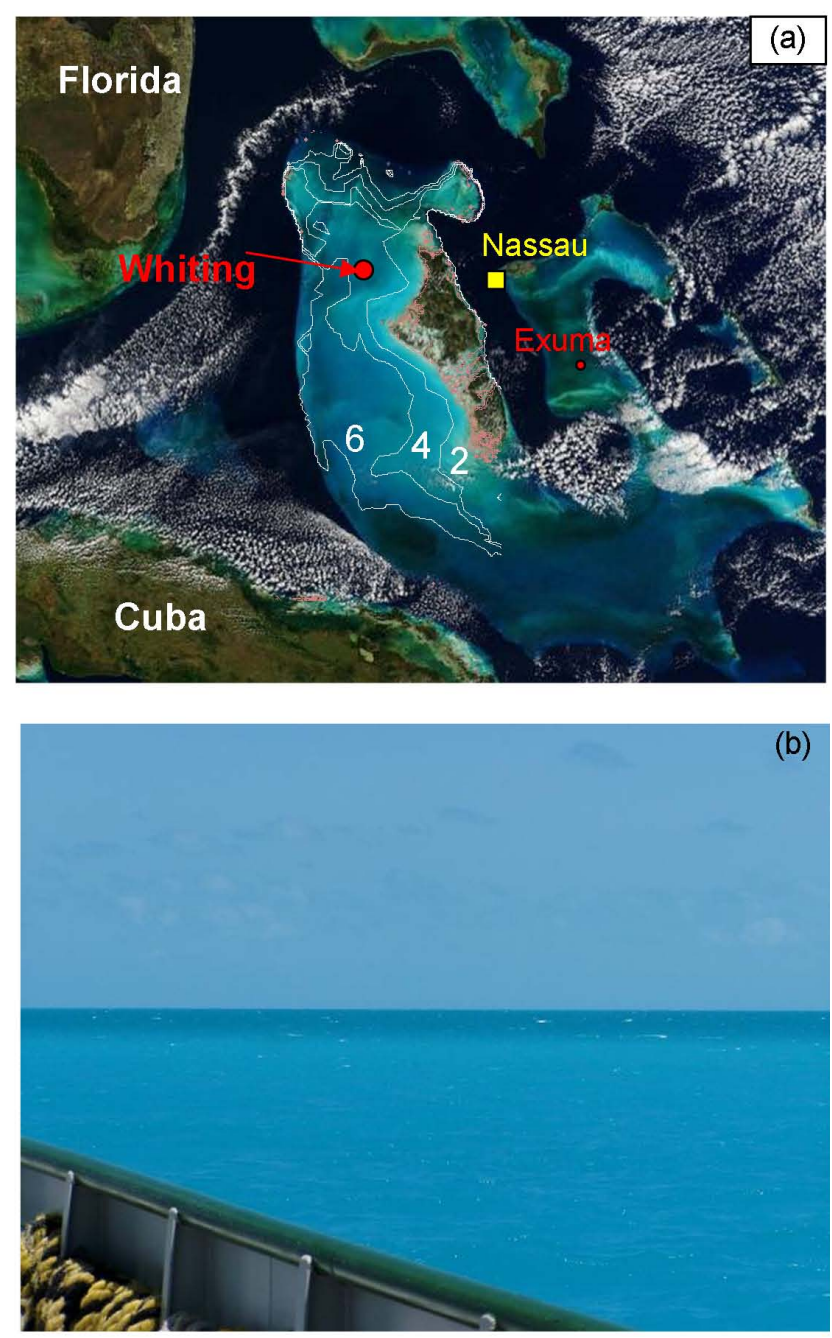

Fig. 1. (a) Pseudo true colour image from MODIS Aqua of the Bahama Banks showing the locations of the Whitings Station, Exumas Station, and the Nassau meteorological station. Bathymetry contours in the region of the whiting from soundings reduced to the lowest astronomical tide (2, 4, $6 \mathrm{~m}$ contour intervals shown). (b) Picture of the whitings patch illustrating the boundary between turbid whiting and darker non-whitings water.

error in the atmospheric correction, a single linear correction (slope and offset) was made to the entire image by comparing $R_{r s}$ derived from the MODIS sensor with a selection of in situ measurements from selected stations $(\sim 6)$ that were spatially consistent over kilometre scales and presumed to be relatively stable in water column optical properties over the course of the study. The whitings station was not included in the scaling correction.

Wind data at 10-m height from the Nassau International Airport (780730, MYNN) and George Town/Exuma (780920, MYEG) were obtained from the National Oceanic and Atmospheric Administration (NOAA) National Environmental Satellite, Data, and Information Service, National 
Climatic Data Center (NCDC) for the period 1999-2004. Daily mean wind speed and maximum sustained wind speed were calculated from hourly meteorological by the NCDC to the nearest 0.1 knot. Wind speed was also measured on the $R / V$ Walton Smith $(\sim 7 \mathrm{~m}$ height) and corrected to true velocity (speed and direction).

Sediment grain size was determined by wet sieving of surface sediments collected by divers, using sieves of the following sizes: $2 \mathrm{~mm}, 600 \mu \mathrm{m}, 125 \mu \mathrm{m}$ and $63 \mu \mathrm{m}$ (see $\mathrm{Hu}$, 2007 for details). The $<63 \mu \mathrm{m}$ fraction was defined as the fine fraction (e.g., Bennett et al., 1990). The frequency of whitings in the Bahama Banks were calculated by Robbins et al. (1997) from photographs taken from astronauts aboard manned spacecraft as catalogued with the NASA Space Shuttle Earth Observation Project (1965 to 1993) (Tau, 1994). A frequency index was calculated from over 888 identified whitings as the monthly whitings area normalized to mission day (Robbins et al., 1997). The frequency index allowed normalization of the data to eliminate bias introduced by uneven distribution of mission days.

\section{Results}

On 28 March 2004, a whiting event was encountered at $25^{\circ} 03.090^{\prime} \mathrm{N}, 78^{\circ} 42.324^{\prime} \mathrm{W}$ 16:55 Greenwich Mean Time (GMT) on the western arm of the Great Bahama Bank, approximately $30 \mathrm{~km}$ west of Andros Island, the largest island of the Bahamas archipelago (Fig. 1a). The water appeared turbid and chalky throughout the $5.3 \mathrm{~m}$ water column, as assessed by divers, and the whiting persisted for tens of square kilometres. When we reached the edge of the whiting, it was easily delimited on the horizon as clearer dark blue water contrasted against the bright turquoise water within the whiting (Fig. 1b). The skies were cloud-free, winds were approximately $7.7 \mathrm{~m} \mathrm{~s}^{-1}$ at the Nassau airport, and the sea surface had little to no swell. Winds measured aboard the vessel were $5.7 \mathrm{~m} \mathrm{~s}^{-1}$ predominantly from the west-northwest $\left(291^{\circ}\right)$. The water temperature measured $22.3^{\circ} \mathrm{C}$ with a salinity of 37.51 . Wave height was estimated at less than $0.1 \mathrm{~m}$. The location and characteristics of this whiting event were consistent with previously observed whitings in this region (Robbins et al., 1997; Shinn et al., 1989).

Sediments in the region are generally unconsolidated carbonate muds and fine sands, with much less extensive biofilm coverage than that on the sediments along the Exumas arm of the Great Bahama Bank. Mean sediment grain size was $382 \mu \mathrm{m}$ at the Andros Station, significantly finer than the mean grain size encountered along the Exumas $(\sim 802 \mu \mathrm{m})$ (Fig. 2, Hu, 2007; also see similar observations in Bennett et al., 1990). The percentage of fine-grained material was $10-16 \%$ of the total, as compared to $\sim 1 \%$ at the Exumas.

Spectral particulate and dissolved absorption, $a_{p g}(\lambda)$, decreased with increasing wavelengths for all stations sampled
(Fig. 3a). The small absorption peak at $676 \mathrm{~nm}$ for all regions sampled indicated fairly low amounts of phytoplankton in the water column $\left(\sim 0.4 \mathrm{mg} \mathrm{Chl}-a \mathrm{~m}^{-3}\right)$ and chlorophyll fluorescence collected underway from the ship revealed concentrations around $0.2 \mathrm{mg} \mathrm{Chl}-a \mathrm{~m}^{-3}$. The magnitude of $a_{p g}$ at the whitings station (solid line) was similar to the magnitude measured at the other stations in the Bahamas (dotdashed line) and that measured near Lee Stocking Island (Boss and Zaneveld, 2003). The spectral shape of absorption is consistent with waters dominated by coloured dissolved organic matter (e.g., produced by benthic vegetation) or detrital/minerogenic particles.

The spectral beam attenuation coefficient, $c_{p g}$ (Fig. 3b), was four times higher $\left(>1 \mathrm{~m}^{-1}\right)$ and the particulate backscattering, $b_{b p}$, was nearly an order of magnitude higher $(0.04$ $0.06 \mathrm{~m}^{-1}$ ) at the whitings station relative to the mean observed for the Bahama Banks (Fig. 3c). The spectral slope of backscattering was negative for all of the stations measured in the Bahamas ranging from -1.3 for the whiting station compared to -1.45 for the rest of the Bahama Banks. The particulate scattering coefficient, $b_{p}(555)$, was used to estimate total suspended matter (TSM) in the water column. The relationship between $b_{p}(555)$ and TSM varies depending on the type and size of particles, but the ratio between the two parameters generally ranges between 0.1 and $2 \mathrm{~m}^{2} \mathrm{~g}^{-1}$ throughout the world's oceans (Baker and Lavelle, 1984; Kirk, 1980), with a mean of around $0.5 \mathrm{~m}^{2} \mathrm{~g}^{-1}$ for coastal waters (Babin et al., 2003). For turbid shallow waters of Florida Bay, the $b_{p}(555) / T S M$ relationship measured in waters dominated by carbonate mud was $0.22 \mathrm{~m}^{2} \mathrm{~g}^{-1}$ (data not shown). Recent determinations of the mass-specific scattering of small-sized (generally less than $10 \mu \mathrm{m}$ ) calcite particles suspended in seawater obtained from direct measurements were $1 \mathrm{~m}^{2} \mathrm{~g}^{-1}$ (Stramski et al., 2007). Using the measured $b_{p}(555)$ at the Andros Station of $0.85 \mathrm{~m}^{-1}$, the suspended particulate load was on the order of $1-5 \mathrm{mg} \mathrm{L}^{-1}$ depending on the relative contribution of aragonite needles to other constituents in the water column.

The backscattering ratio, $\tilde{b}_{b p}$, was measured across 24 stations of the Bahama Banks. The highest ratio was measured at the whitings station where $\tilde{b}_{b p}$ was $0.060,0.049$, and 0.048 for 470,530 and $650 \mathrm{~nm}$, respectively (Fig. 3d). The backscattering ratio was also used to estimate the bulk refractive index of particles following the methods of Twardowski et al. (2001) based on the slope of the particle size distribution and the backscattering ratio. The slope of the particle size distribution, not measured directly, was estimated from the wavelength-dependence of the particulate attenuation coefficient (Boss et al., 2001). The attenuation coefficient measured in the field was not partitioned into that due to dissolved and particulate materials. For the whitings station, we assumed that light attenuation due to the dissolved constituents was insignificant compared to the suspended particles and, hence, $c_{p}$ was equivalent to $c_{p g}$. The wavelength spectrum of $c_{p}$, for a dispersion medium with negligible 


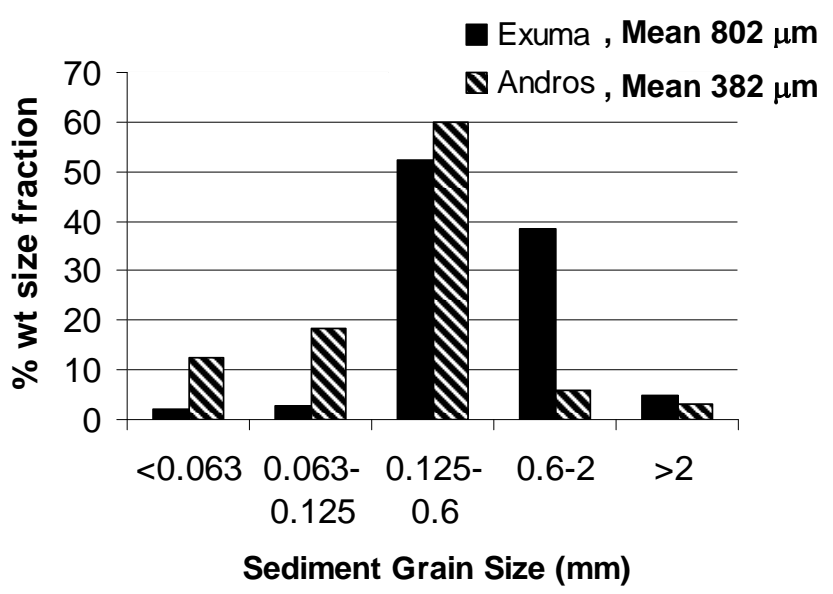

Fig. 2. Sediment grain size determined from sediment cores collected in the Exumas (Eastern) and Andros (Western) regions of the Bahama Banks.

absorption of light, follows a power-law, such that:

$c=A \lambda^{-\gamma}$

where $\lambda$ represents the eight visible wavelengths measured by the $a c-9, A$ is a constant, and $\gamma$ is the hyperbolic slope. At the whitings station, the calculated slope, $\gamma$ for the whiting station was 0.78 . A bulk index of refraction could theoretically be estimated from approximations of the slope of the particle size distribution (Boss et al., 2001) and the particulate backscattering ratio (Twardowski et al., 2001). Such an approach was not applied here because particles within a whiting may not be spherical (Shinn et al., 1989) and the particle size distribution may not be strictly Jungian. However, the high particulate backscattering ratio is consistent with a water column dominated by aragonite minerals with a high index of refraction of 1.22 relative to water (i.e., 1.632-1.633 in its dry state; Aas, 1996).

Optical data were sampled over a 6-minute interval at each station at a fixed depth of $\sim 2 \mathrm{~m}$. The time series of water column optical properties collected over time at the whiting station revealed periodicity and larger variability compared to other stations from the Bahamas (Fig. 4a-d). The attenuation coefficient, $c_{p g}$, was sampled at $\sim 6 \mathrm{~Hz}$ temporal resolution and the backscattering data from the ECO-VSF, shown here as the volume scattering, $\beta$, at $125^{\circ}$ and $532 \mathrm{~nm}$, was sampled at $\sim 1.2 \mathrm{~Hz}$. At the whiting station, mean $c_{p g}(555)$ was $0.932 \pm 0.10$ and $\beta(532)$ was $0.008 \pm 0.001$. In comparison, data from Station 18 , sampled $2 \mathrm{~h}$ earlier and $24.5 \mathrm{~km}$ to the east, revealed significantly less variability over the time course of sampling and had mean $c_{p}(555)$ of $0.326 \pm 0.004$ and $\beta(532)$ of $0.002 \pm 0.0002$. Similar low standard deviations were observed in Station 21 located $19.6 \mathrm{~km}$ to the south and Station 7 located on the arm of the Exumas.
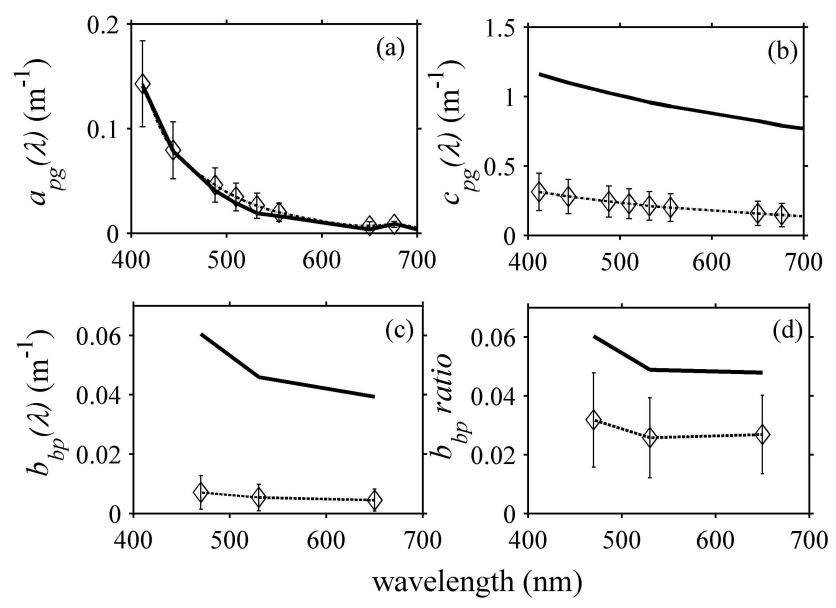

Fig. 3. Inherent optical properties measured at the whitings station (solid line) compared to the mean (dot-dashed line) and standard deviation (errorbars) measured at twenty-one other stations located throughout the Bahama Banks: (a) absorption by particulate and dissolved material $\left(a_{p g}\right)$; (b) attenuation by particulate and dissolved material $\left(c_{p g}\right)$; (c) backscattering of particulate; and (d) backscattering ratio illustrating high mineral content at the whitings station.

Regular periodicity was also evident in the optical data from the whitings (Fig. 4b and d). A discrete Fourier transform was conducted with the 6-min time series to find potential frequency components of the signal within the data noise. The data were detrended using the best straight-line fit linear trend. The single-sided amplitude spectrum of the Fourier transform revealed enhanced amplitudes at frequencies of $0.03 \mathrm{~Hz}$ and $0.008 \mathrm{~Hz}$, which correspond to time intervals of $30-40 \mathrm{~s}$ and $2 \mathrm{~min}$. Such periodicity was not evident at the other stations which had similarly low amplitudes for all frequencies. The $6 \mathrm{~Hz} c_{p g}(555)$ data had a higher amplitude signal at $30 \mathrm{~s}$ periodicity than the backscattering data sampled at only $1 \mathrm{~Hz}$. The Nyquist frequency was $2.941 \mathrm{~Hz}$ for the $c_{p g}(555)$, but little energy was found at high frequencies for all of the stations sampled.

Because of the relatively short time series and the amount of energy at low frequencies, maximum entropy techniques were also applied to the optical time series (Fig. 5). The graph was truncated at $0.2 \mathrm{~Hz}$ because no energy was found at higher frequencies. The $c_{p g}(555)$ data were detrended using a quadratic function which accounted for about $50 \%$ of the variance. Before trend removal the autocorrelation function at lag $1=0.9894$ and after removal it is 0.9813 . The spectrum was normalized by the variance of the data after trend removal. The confidence limits were calculated by assuming that the data are "red" noise using an AR(1) model with the same autocorrelation function at lag 1 as that of the data and chi-squared levels. The two large peaks in the spectrum that rise above the $99 \%$ confidence limits are at periods of 212.5 and $42.4 \mathrm{~s}$. 

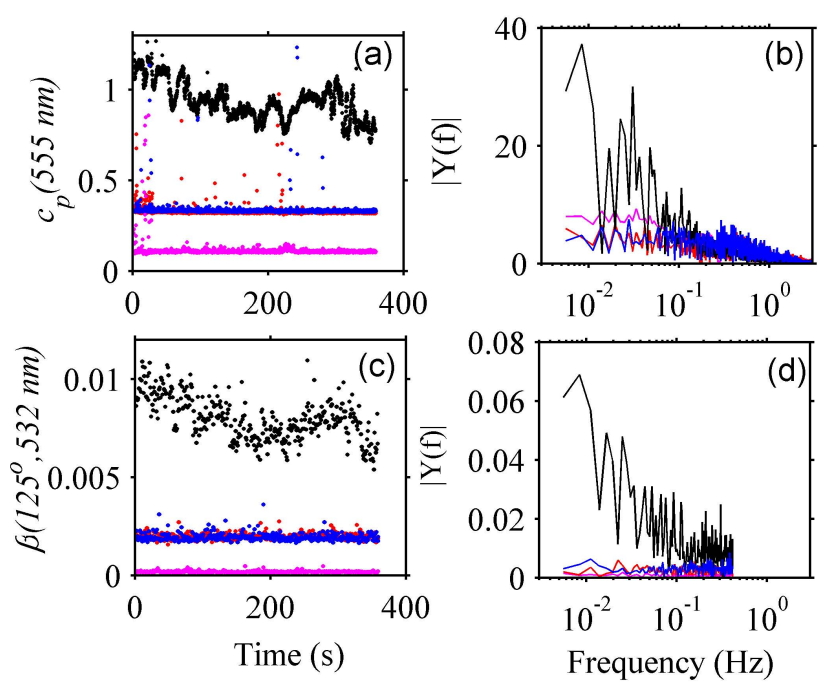

Fig. 4. (a) Time series of particulate attenuation, $c_{p}(555)$, measured at the whitings station (\#19, black), compared to other stations in the vicinity (\#18, 21, blue and red) and the Exumas station (\#7, magenta). (b) Fourier transform of the data from (a). (c) Time series of the $1.2 \mathrm{~Hz}$ backscattering data from the ECO-VSF, $\beta 125^{\circ}$, $532 \mathrm{~nm}$; (d) Fourier transform of data from (c).

Remote sensing reflectance, $R_{r s}(\lambda)$, is proportional to the ratio of backscattering to absorption properties of the water column. The reflectance spectrum, $R_{r s}(\lambda)$, measured at the whiting station was large in magnitude $\left(>0.05 \mathrm{sr}^{-1}\right)$ and peaked at approximately $488 \mathrm{~nm}$, in the blue/green portion of the visible spectrum (Fig. 6). The magnitude of reflectance was much higher than that measured over stations of similar bathymetry $(\sim 5 \mathrm{~m})$, but with seafloors comprised of sand and the benthic macroalgae, Colpomenia sp. from the Exumas. The $R_{r s}(\lambda)$ spectrum was similar in shape compared to that from nearby station \#18 similarly containing a fine aragonite mud seafloor with very sparse seagrass, but the reflectance is significantly elevated across the spectrum at the whiting station. Such elevated reflectance is consistent with the elevated backscattering properties found within the whiting and high concentrations of fine suspended minerals (see Fig. 3c). The perceived colour of the water column was modelled using the reflectance spectrum following techniques in Dierssen et al. (2006) and is reproduced in the coloured boxes and line colour on Fig. 6. The modelled colour at the whiting station was a bright turquoise colour that paralleled the colour observed in the field (see Fig. 1b).

Satellite imagery from the MODIS Aqua sensor was collected from available passes over the Great Bahama Bank coincident with the field campaign. Clear sky imagery was available on 6, 16, 18, 22, 27, and 30 March 2004. The pseudo true colour images revealed regions of bright turquoise around Andros Island due to the shallow $<2 \mathrm{~m}$ water depths in this region, darker blue waters to the west of the island where the whiting was observed, and some

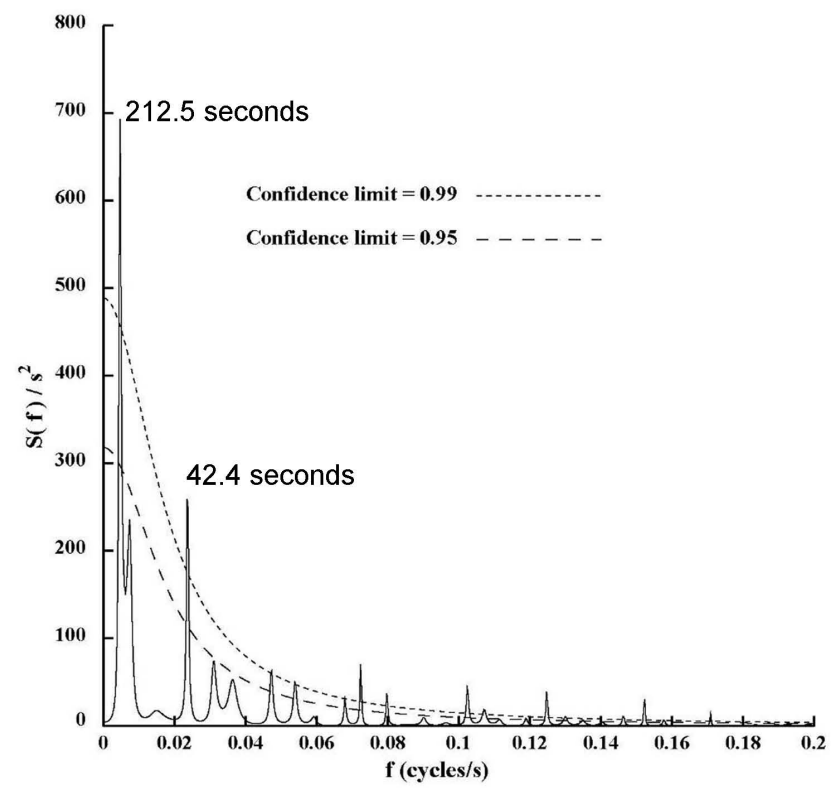

Fig. 5. Maximum entropy spectrum of whitings $c_{p}$ (555) time series data (from Fig. 4a) showing significant peaks at 212 and $42 \mathrm{~s}$.

green patches to the north that are associated with seagrass/algal growth on the seafloor (Fig. 7a-f). The black regions along the Bank indicate areas obscured by clouds where the ocean colour cannot be observed. Imagery from 16, 18, and 22 March 2004 revealed transient bright white patches of water in the vicinity of the observed whiting. The whitings patches are generally small and vary in precise location depending on the day of observation. Brighter white in the imagery is suggestive of high sediment resuspension events similar to a whiting.

Pseudo true colour imagery from 22 March 2004 was magnified to highlight the water properties in the vicinity of the whitings station (Fig. 8a). From this image, several parallel patches of whiter water were observed that were oriented roughly in a north-westerly pattern. Maps of the whitings patches were generated from the atmospherically corrected satellite imagery by matching the magnitude of the retrieved spectral reflectance in available multi-channel wavebands $(412,443,488,551$, and $667 \mathrm{~nm})$ to the in situ spectrum (Fig. 8b). Patches were identified in the vicinity of Station 19 near the location of the observed whiting where $R_{r s}$ closely matched both the magnitude and spectral shape of the whitings station. As shown, retrieved $R_{r s}$ in the white patches was nearly coincident with field measurements for 412,443 , and $667 \mathrm{~nm}$. Peak $R_{r s}$ occurred at $488 \mathrm{~nm}$ in the imagery, but the magnitude was slightly reduced compared to the measured spectrum. The regions highlighted in red covered approximately $18 \mathrm{~km}^{2}$ (Fig. $8 \mathrm{c}, \mathrm{d}$ ).

The temporal pattern of whiting observations is consistent with a wind-driven process such as Langmuir circulation. The wind speed necessary to create Langmuir super- 
cells across a 5-m depth can be estimated using formulations provided for homogenous water in fully developed seas $(\mathrm{Li}$ and Garrett, 1997). The depth of penetration, $d$, of Langmuir circulation is a function of wind speed at $10 \mathrm{~m}$ height, $u$, and water column stability, defined as the Brunt-Väisala or buoyancy frequency $(N)$ :

$d=1.7 w_{d n} N^{-1}$

$w_{d n} \approx 0.008 u$

$u \approx 73.53 d N$

Assuming a buoyancy frequency of $0.02 \mathrm{~s}^{-1}$, Langmuir cells penetrating $5 \mathrm{~m}$ in water depth could be produced from sustained winds of $7.35 \mathrm{~m} \mathrm{~s}^{-1}$ or greater. Such winds were observed at the study site during the time of the whiting and the Exumas windrow observations (Fig. 9a). Maximum sustained wind speed obtained from the closest meteorological station, Nassau airport (Fig. 1a) showed that speeds exceeding this threshold are common to the Bahama Banks. High winds occur least frequently in summer (Fig. 9b). Seasonal estimates of whitings determined from low earth orbit photography obtained sporadically from 1965-1993, although not temporally coincident with the wind data, show that whitings on the Great Bahama Bank also occur less frequently in summer months than at other times of year (Fig. 9c).

\section{Discussion}

\subsection{Optical characterization of whitings}

Optical properties measured in the field confirmed the presence of highly turbid sediment-laden water on the Great Bahama Bank west of Andros Island. The observed whiting occurred over fine mud and pellet-mud sediment facies (Purdy, 1963) in $5.3 \mathrm{~m}$ of water in the same region of the Banks that the majority of previous whiting observations have been made (Shinn et al., 1989; Robbins et al., 1998). The water was a turquoise colour and had much higher light attenuation, backscattering, and reflectance compared to any of the other stations sampled in the Bahama Banks. The spectral absorption signatures measured for the whiting and other stations throughout the Bahamas were similar in shape and magnitude to those measured near Lee Stocking Island, Bahamas and were consistent with waters dominated by coloured dissolved organic matter (e.g., produced by seagrass meadows and coral reefs) (Boss and Zaneveld, 2003; Otis et al., 2005) or resuspended sediment. The absorption coefficient was not enhanced for the whitings stations compared to other stations and confirmed the presence of low-light absorbing minerals. Past studies have shown that particulate absorption by both calcareous sand and coccolithophores (comprised of a related mineral calcite) were low in the visible wavelengths (Ahn, 1990; Balch et al., 1991; Stramski et al., 2007). Robbins and

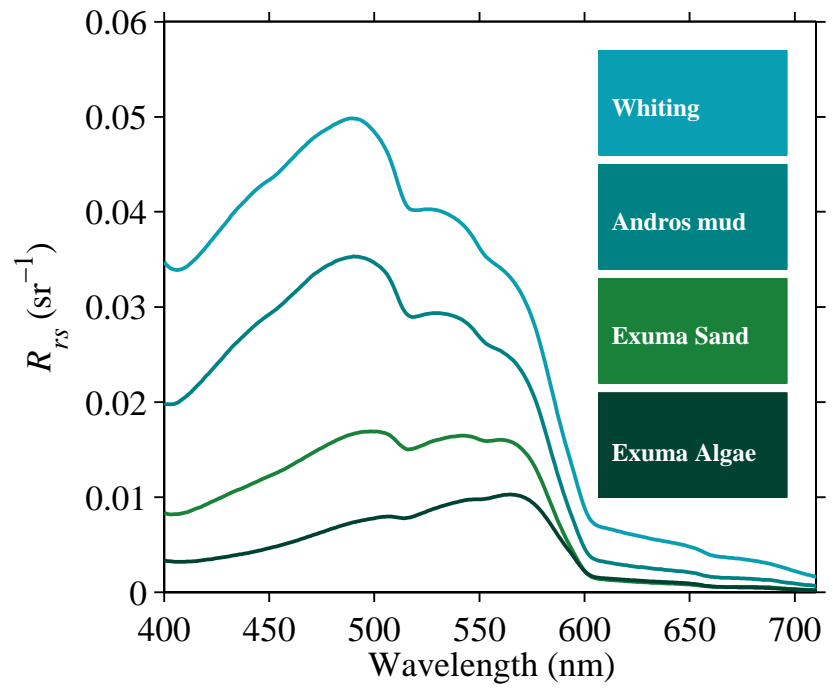

Fig. 6. Remote sensing reflectance, $R_{r s}$, measured over a selection of stations with $5 \mathrm{~m}$ depth and benthic constitutents varying from whitings station, Andros mud, Exuma sand, and Exumas algalcovered grapestone sediment. Line colour and coloured boxes show the perceived colour of each spectrum quantified following the approach in Dierssen et al. (2006).

Blackwelder (1992) found that the centre of the aggregated aragonite minerals in a whiting consisted of organic material including membranes of whole picoplankton. Our measurements of particulate and dissolved absorption at $676 \mathrm{~nm}$ in the whitings revealed a slight enhancement of chlorophyllcontaining particles (i.e. phytoplankton, $\sim 0.4 \mathrm{mg} \mathrm{m}^{-3}$ ) compared to regions outside the whitings. This is consistent with the presence of phytoplankton debris found in sediment filtered from whitings (Shinn et al., 1989).

The negative wavelength-dependence of particulate backscattering, $b_{b p}$, at the whiting station $\left(\lambda g^{1.3}\right)$ was consistent with high concentrations of small particles (Morel and Bricaud, 1981; Morel and Maritorena, 2001). The grain size of the suspended particles was not measured directly, but previous research has shown individual aragonite needles from both the sediment and water column to be approximately $0.25 \mu \mathrm{m}$ wide and $2-3 \mu \mathrm{m}$ long with a rectangular or hexagonal shape (Shinn et al., 1989). Electron micrographs of particles filtered from whitings also revealed aggregations of aragonite needles that formed $10-15 \mu \mathrm{m}$ peloids (see Fig. 10 in Shinn et al., 1989). High concentrations of suspended aragonite particles would enhance the amount of backscattered light considerably (reviewed in Stramski et al., 2004). Here, we found backscattering to be nearly 10-fold higher than for other waters along the Bahama Banks. The estimated mass of suspended matter (1-5 $\left.\mathrm{mg} \mathrm{L}^{-1}\right)$ in the whiting was not high compared to other waters where concentrations can reach hundreds of $\mathrm{mg} \mathrm{L}^{-1}$ (e.g., see Miller and McKee, 2005); however, this 
(a) 6 March 2004

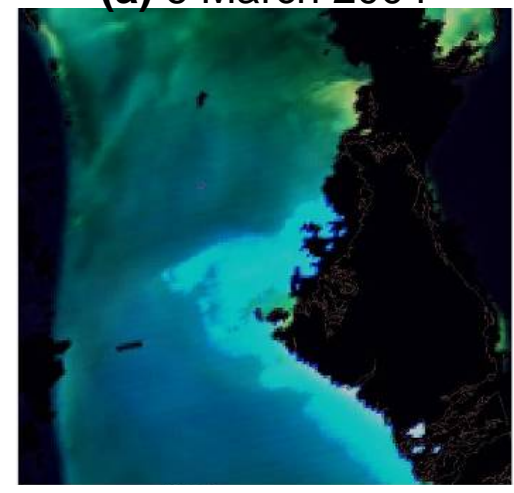

(d) 22 March 2004 (b) 16 March 2004

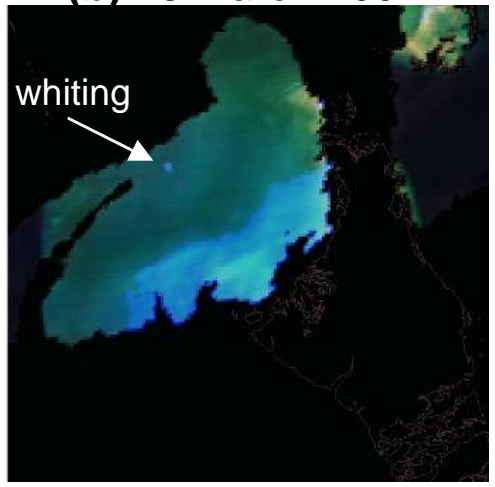

(e) 27 March 2004
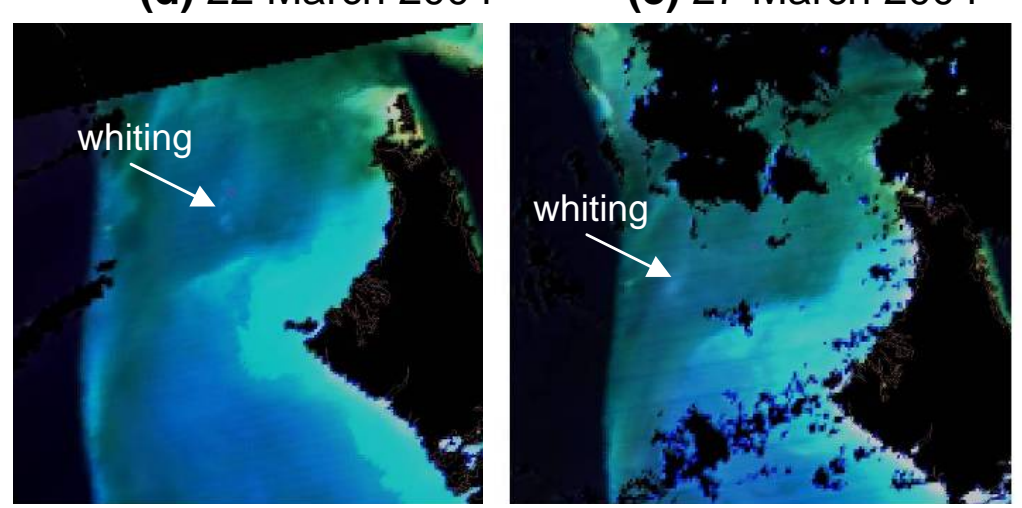

(c) 18 March 2004

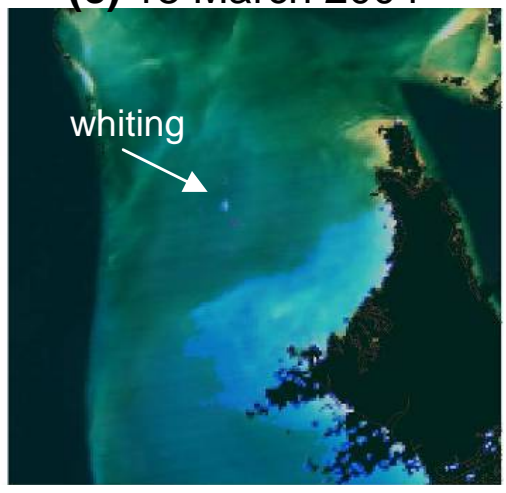

(f) 30 March 2004

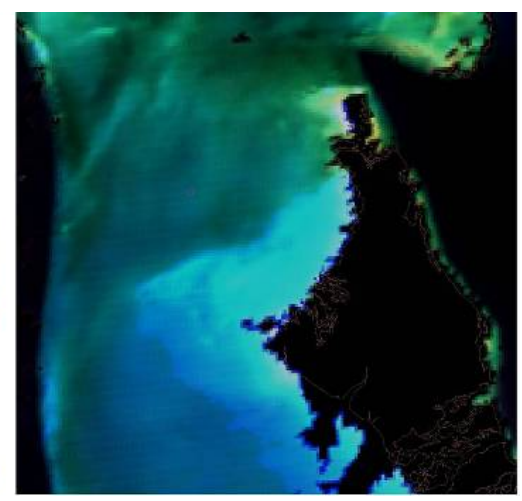

Fig. 7. Pseudo true colour images from the MODIS Aqua satellite obtained on clear sky conditions during the March 2004 field campaign. Patches of turbid white water have been identified visually in several of the images.

mass-specific concentration translates to a considerable number of micron-scale particles and aggregated particles suspended in the water column.

The particulate backscattering ratio $\left(\tilde{b}_{b p}\right)$ provided additional information about the composition of particles suspended in the water column, particularly the amount of inorganic materials (i.e., suspended sediments) with a high refractive index relative to water (Ulloa et al., 1994; Twardowski et al., 2001). The measured ratio $5-6 \%$ is one of the highest values reported in natural waters and characteristic of water dominated by inorganic or mineral sediment (Twardowski et al., 2001; Sullivan, et al., 2005; Whitmire et al., 2007). In turbid coastal waters of the Black Sea, for example, Chami et al. (2005) found $\tilde{b}_{b p}$ to be $4 \%$. McKee et al. (2005) found high backscattering ratios around 5\% from one sampling day in the Irish and Celtic Seas similar to these waters. Moreover, the particles found in whitings are typically non-spherical needles or aggregates of these needles (Shinn et al., 1989). Particles which deviate from sphericity generally serve to enhance the backscattering ratio (Clavano et al., 2007).
Little to no spectral dependency is typically found in $\tilde{b}_{b p}$ measured over a wide range of natural water types and particle populations (Whitmire et al., 2007), as was evident in the average measurements for the Bahamas. Under certain conditions, however, enhanced $\tilde{b}_{b p}$ in blue wavelengths has been measured (McKee and Cunningham, 2005), similar to that found at the whitings station. Conditions that might cause wavelength-dependence would occur when the particle size distribution contains modes of particles and the particle size distribution does not closely follow a Jungian or power-law distribution. Such a situation may be possible in these highly scattering waters dominated by monospecific suspension of micron-scale particles.

The pumped water input system of the instrumentation used to measure the light absorption and attenuation properties of the whitings can break up or exclude aggregates from the measurements (Slade and Boss, 2008). Hence, the attenuation and absorption measurements may not properly represent aggregated peloids found in whitings (Shinn et al., 1989). Additional research is necessary to more fully characterize the optical properties of the particles concentration and size spectrum, volume scattering function, and the backscattering properties of these unique waters. 

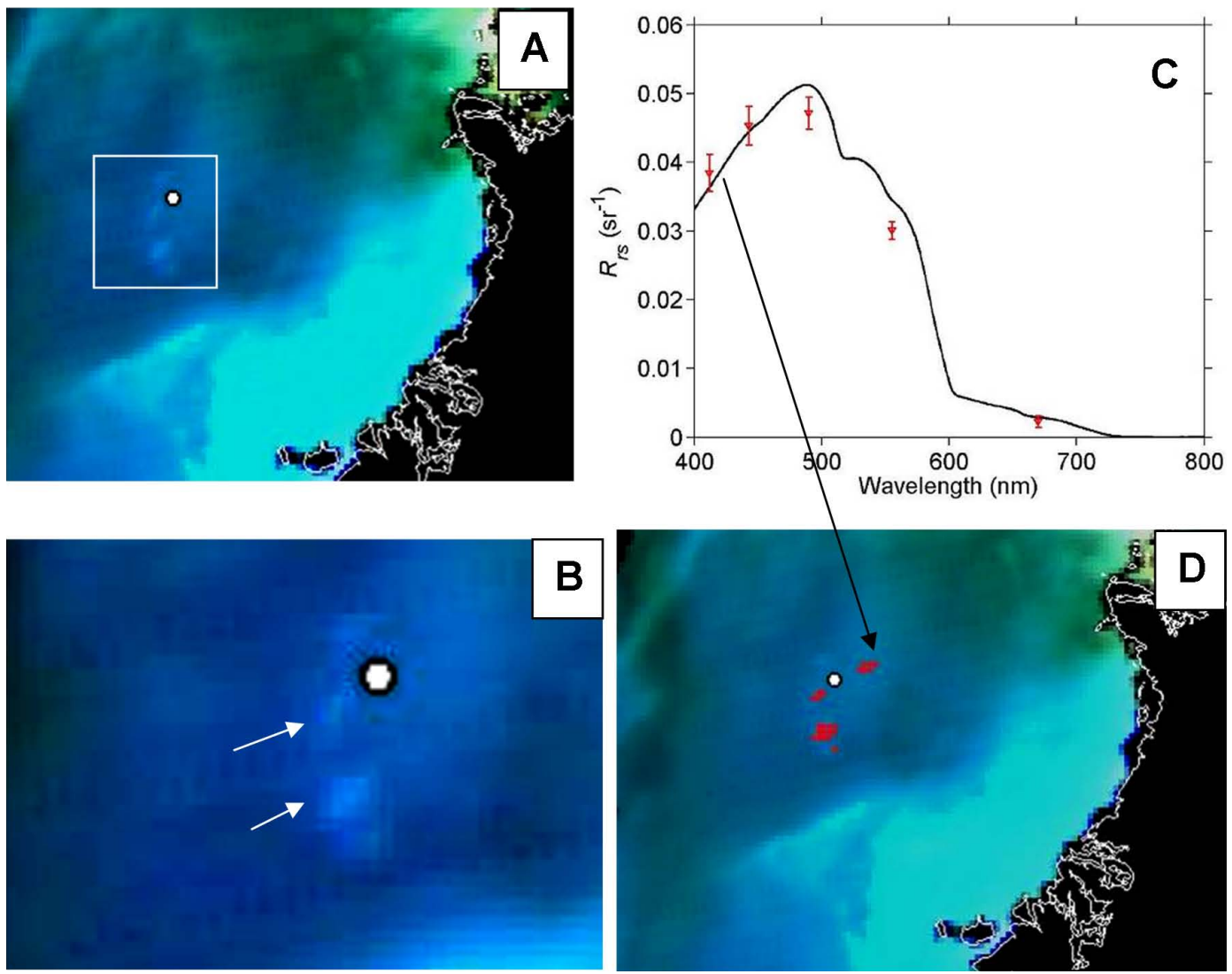

Fig. 8. (a) MODIS pseudo true colour image from 27 March 2004 showing the location of the whitings station (white circle) and Andros Island outlined to the east. The whiting was encountered in the field one day later on 28 March 2004. (b) Highlight of region from (a) with arrows pointed to the highly reflective regions; (c) Spectral remote sensing reflectance, $R_{r s}$, from the whitings patches in the atmosphericallycorrected MODIS imagery (red points with error bars) compared to in situ $R_{r s}$ measured at the whitings station (black line). (d) Red regions identified as having spectral $R_{r s}$ closely corresponding to the in situ whitings $R_{r s}$.

The high backscattering characteristics of whitings were detectable in remote sensing imagery from the MODIS Aqua satellite. White patches were evident in the pseudo true colour images of the Andros arm of the Bahama Banks throughout the month of March 2004. Such white patches have also been observed and enumerated using space shuttle photography (Robbins et al., 1997). Moreover, our radiometric analysis of atmospherically-corrected imagery showed satellite-derived reflectance across visible channels comparable to in situ measurements. Specifically, the imagery showed an $18-\mathrm{km}^{2}$ patch in the vicinity of the whiting station that had elevated $R_{r s}$ peaking at $\sim 490 \mathrm{~nm}$ with a magnitude near $0.05 \mathrm{sr}^{-1}$. Suspended sediment was also observed as elevated backscattering in regions outside the whitings, but concentrations were not sufficiently high to appear white to the human eye. Such subtleties in the magnitude of spectral reflectance, however, could be observed in the imagery and used to routinely monitor the total suspended particle load from space. However, challenges will exist in decoupling the contributions of water column properties from the effects of bathymetry and bottom reflectance in these regions using the limited spectral information currently available. The whiting $R_{r s}(\lambda)$, for example, is similar in shape and magnitude to that measured in the Exumas over bright oolitic sand in clear sediment-free water of only $2.8 \mathrm{~m}$ depth (Dierssen et al., 2003).

\subsection{Whitings and wind-driven processes}

Radiocarbon data of whitings allow for some (less than $\sim 15 \%$ ) new carbonate material (i.e., recent precipitates), but most is "older" material consistent with the radiocarbon age of the underlying sediments (Broecker et al., 2000; Bustos-Serrano et al., 2009). No single hypothesis for sediment resuspension has been widely accepted by the scientific community. Results from this study lead us to suggest a possible wind-driven sediment resuspension caused by Langmuir circulation in shallow water (Gargett et al., 2004). Langmuir circulation is generally observed as pairs of parallel counter-rotating cells oriented in the downwind direction and are caused by the interaction between winddriven shear current and the Stokes drift current from surface 

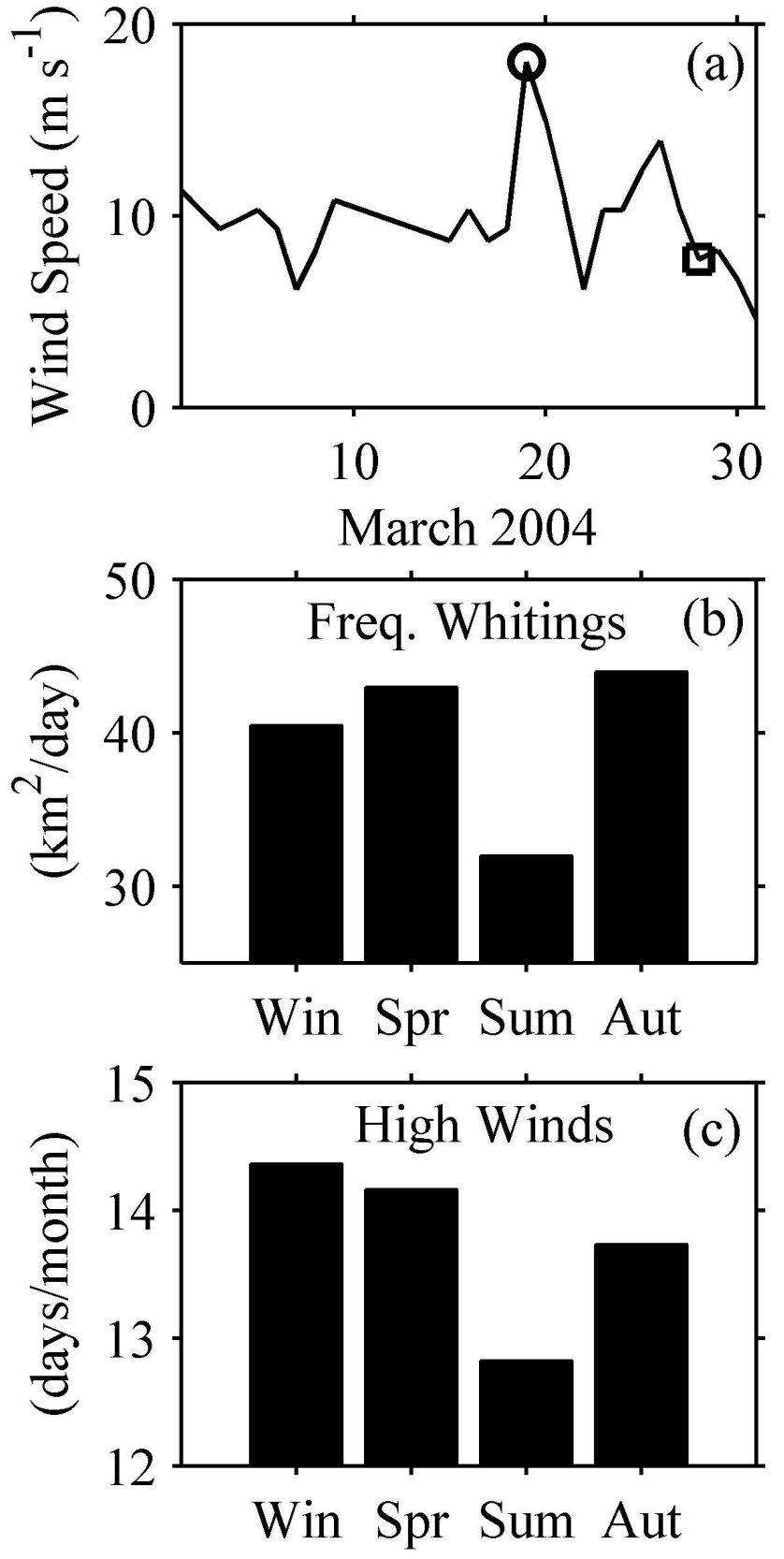

Fig. 9. (a) Maximum sustained wind speed $\left(\mathrm{m} \mathrm{s}^{-1}\right)$ from the Nassau meteorological station for the month of March 2004 highlighting wind speed during the whiting event. (b) Seasonal frequency index of whitings determined on the Great Bahama Bank from low earth orbit space shuttle photography obtained sporadically from 1965-1993 (adapted from Robbins et al., 1997). (c) Seasonal frequency (number of days per month) of maximum sustained wind speeds at the Nassau meteorological station exceeding $7.35 \mathrm{~m} \mathrm{~s}^{-1}$, which is the threshold estimated to cause 5-m penetrating Langmuir cells in waters with low stratification (buoyancy frequency of $\left.0.02 \mathrm{~s}^{-1}\right)$. gravity waves (Thorpe, 2004). Langmuir cells can extend in the downwind direction for tens of meters to kilometres in spatial scale (Tejada-Martinez and Grosch, 2007). Those cells that can extend vertically the full depth of the water column have been shown to resuspend and transport sediment (Gargett and Wells, 2007). We propose that wind-driven Langmuir circulation is a plausible mechanism for sediment resuspension in this region that is consistent with our data and past studies on whitings, particularly the extensive field observations made by Shinn et al. (1989).

First, Langmuir cells reaching the full extent of a 5-m depth water column were visually observed earlier in March 2004 on the eastern Exuma region of the Bahamas as regular rows of the benthic algae, Colpomenia sp., concentrated on the seafloor (Dierssen et al., 2009). Moreover, Langmuir supercells have previously been associated with resuspended sediments off the western Atlantic shelf in the LEO-15 site (Gargett et al., 2004). Langmuir cells serve to homogenize vertical velocity throughout most of the water column (Tejada-Martinez and Grosch, 2007) and could serve to resuspend sediment from near-bottom flows up throughout the water column (Gargett et al., 2004). Current velocities required to resuspend the fine aragonite muds on Andros would be less than that required to suspend larger-grained sediments common to other parts of the Bahamas. Although not measured here, previous research using an underwater flume indicates that currents in excess of $20 \mathrm{~cm} \mathrm{~s}^{-1}$ are necessary to erode and suspend bottom sediment from the region west of Andros Island (Shinn et al., 1989). Compared to other types of wind-driven turbulence (e.g., Couette turbulence), Langmuir cells produce maximum turbulent flow 3-10 times greater in all fluctuating velocity components and significant turbulent kinetic energy in near-bottom waters (TejadaMartinez and Grosch, 2007) .

The visible manifestation of Langmuir cells as defined windrows was not readily detected from the coarse spatial scale of the MODIS imagery, nor was it evident from our casual observations with the unaided human eye. However, regular periodicity in the optical measurements (Fig. 4) indicated the presence of alternating patches of more and less turbid water (i.e., regularly fluctuating $c_{p}$ and $b_{b p}$ ) that may give whitings the visible "rolling" nature that has been attributed to past whitings (Shinn et al., 1989). Such periodicity was not evident in any other station sampled during this cruise and was not due to vertical movement of the profiling package, which remained at a fixed depth of $2.8 \pm 0.047 \mathrm{~m}$ throughout the duration of the time series. We were unable to estimate the potential size of Langmuir cells from the periodicity measurements because no ancillary current measurements were obtained to differentiate the various components of the velocity field and the expected period of cell crossing. Our optical in situ data were obtained on an anchored ship that might have had lateral movement across cells. However, we note that the observed periodicity indicated patches of fluctuating turbidity on spatial scales that 
could be produced from regular rows of Langmuir cells penetrating the full 5-m water column. The fine-grained sediments common to the Andros region (Fig. 2) can stay suspended in the water column for considerable time and the presence of defined windrows will become more and more obscured over time. Hence, rather than producing clearly discernable windrows, Langmuir cells could produce mixed suspensions of fine aragonite mud throughout the water column.

Prior research on Bahamian whitings also give indications of periodicity at the boundaries of the whitings patches that may be associated with Langmuir or other types of winddriven turbulence. Shinn et al. (1989) describe most whitings as having a "rolling" nature and billowing downcurrent boundaries composed of "regularly spaced digits" protruding several tens of meters from the main body of the whiting. They note that if the wind is at an angle to the drift, the digits will point into the wind and not the current, which is highly suggestive of a wind-driven mechanism. Furthermore, artificial patches of whitings created by dragging a net over the muddy bottom settled within six hours. Natural whitings can persist for 24-45 h (Shinn et al., 1989; Cloud, 1962) and would likely require a forcing mechanism beyond an isolated resuspension event (e.g., fish activity). The rate of sedimentation previously measured at whitings was as high as $34 \mathrm{~g} \mathrm{~m}^{-2} \mathrm{~h}^{-1}$ and would dissipate a whiting in a few hours if the material in suspension were not continually being replenished (Shinn et al., 1989). Langmuir cells present a mechanism for continued resuspension throughout the duration of a wind event.

These results suggest a mechanism other than those previously proposed for sediment resuspension. Fish activity was not assessed at the site during our investigations, but Shinn et al. (1989) spent considerable effort searching for fish in whitings using sidescan sonar, fathometer imaging, shrimp trawls, and remote video and found no connection to most Bahamian whitings. The scale of the whitings observed from space $\left(\sim 18 \mathrm{~km}^{2}\right)$ seems to be larger than could be produced by isolated shark activity. Moreover, neither fish activity nor tidal bursting is consistent with the regular periodicity observed in our optical measurements. Coincident wind speed measurements were theoretically high enough to produce Langmuir cells covering the full depth of the water column. In addition, historical observations demonstrated the lowest prevalence of whitings during summer months (Robbins et al., 1997), which coincidentally have the lowest wind speeds. Seasonality in whiting observations may not be evident if tidal bursting or fish behaviour were the mechanism for sediment resuspension. Langmuir cells are not readily detectable from traditional current measurements and have been long overlooked as an important mechanism for processes in shallow water, such as resuspension events (Garget et al., 2004).

\section{Conclusions}

Sediment whitings are not merely isolated turbidity events, but have implications for the formation of aragonitic muds found on the western bank of the Great Bahamas Bank near Andros Island (Milliman et al., 1993) and the global carbon cycle. Radiocarbon data published to date suggest that most of the material in whitings is resuspended sediments, but that some amount of recent precipitation may also occur on the particles as they are suspended in the water column (Morse et al., 2003; Bustos-Serrano et al., 2009). Certainly high levels of carbonate precipitation must occur to replenish the considerable amount of sediment lost off the Banks during storm events (Shinn et al., 1993). However, the amount of resuspended sediment in this region and the potential contribution of whiting events to carbonate precipitation has not been well characterized. The ability to monitor and quantify resuspension events in this region with ocean colour remote sensing will allow us to better constrain both regional and global carbon budgets.

The optical characterization of whitings presented here is a first step towards understanding the optical properties of these waters and developing robust remote sensing algorithms. Particulate backscattering was an order of magnitude higher than that measured at other stations throughout the region. The whiting also had one of the highest backscattering ratios measured in natural waters $(0.05-0.06)$ consistent with water dominated by minerogenic particles with a high index of refraction. The composition of particles within whitings has been shown to be a combination of micron-scale aragonite needles, aggregations of these needles, and assorted other organic debris (Shinn et al., 1989).

While whitings are dramatic representations of intense sediment resuspension visible to the human eye, optical measurements from throughout the Andros region suggest that fairly high concentrations of suspended sediments occur outside the whiting boundaries. For example, estimates of backscattering coefficients and backscattering ratios at stations within $25 \mathrm{~km}$ from the whiting were also high indicating elevated concentrations of suspended matter in these neighbouring waters as well. The total amount of carbonate precipitation occurring on these banks will likely be significant when the total suspended sediment occurring both within and outside of whitings is tabulated. Consistent with this suggestion, Morse et al. (2003) similarly note that whiting events are not major sites of carbonate removal on the Great Bahama Bank, since their estimates suggest that $>98 \%$ of the suspended calcium carbonate on the banks is outside of whitings. More measurements are needed to fully characterize the backscattering properties of aragonite needles and aggregates of needles, quantify amounts of these particles suspended in the water column, and develop robust remote sensing algorithms.

Distinct white patches were clearly visible and detectable from pseudo-true colour imagery from the MODIS Aqua 
ocean colour sensor and revealed periodic whiting patches throughout this region during the month of March 2004. Atmospherically-corrected ocean colour imagery echoed the spectral shape and magnitude of the highly reflective waters found in the whiting and allowed us to identify the spatial extent of the whiting patch under investigation. However, challenges exist in decoupling the contributions of water column properties from the effects of bathymetry and bottom reflectance given the limited spectral information currently available in today's ocean colour sensors. Higher spectral resolution capabilities from future satellite sensors may allow for detection of slight variations in the spectral shape that would allow better discrimination of these features. Moreover, high resolution bathymetry will greatly aid in efforts to decouple the bottom from the water column and allow for better remote sensing retrievals. Methods to remotely sense particle sizes and concentrations in the water column will allow us to understand the sediment dynamics in this changing region and related effects on the carbon cycle.

Linking sediment resuspension events to environmental forcings may elucidate how shallow water banks and bays will be influenced by changes in climate patterns that govern regional wind and weather patterns. Further understanding of the forces responsible for creating whitings, such as the potential linkage between Langmuir circulation and whitings described here, is required for elucidating changes in this ecosystem. Quantifying calcification in relation to sediment processes will be important for determining how these regions will respond to changes in ocean acidity due to enhanced atmospheric carbon dioxide (Broecker and Takahashi, 1966; reviewed in Seibel and Fabry, 2003). Certainly, more research on the optical properties of whitings in relation to the physical dynamics of the shallow water environments is warranted in order to asses the potential impact of these biogeochemical processes on coastal ecosystems and global elemental cycles.

Acknowledgements. The authors thank the many individuals who helped collect this data, the crew aboard the $R / V$ Walton Smith, the staff at the Exuma Land and Sea Park, and the Ocean Biology Processing Group (Code 614.2) at the GSFC, Greenbelt, MD 20771, for the production and distribution of the ocean colour data. Chet Grosch provided the maximum entropy analysis and Xinping $\mathrm{Hu}$ provided the grain size analyses. Michael Twardowski provided helpful insight into interpretation of the backscattering data and calculation of the bulk index of refraction. Christopher Buonassissi helped with satellite image processing. Eugene Shinn provided helpful insight and comments regarding whitings research. Financial support was provided by the Chemical Oceanography Program of the National Science Foundation (D.J.B. and R.C.Z.), the National Aeronautics and Space Administration (NASA) Ocean Biology and Biogeochemistry Group (H.M.D. and R.C.Z.), and the Environmental Optics Division, Office of Naval Research (H.M.D.).

Edited by: E. Boss

\section{References}

Aas, E.: Refractive index of phytoplankton derived from its metabolite composition, J. Plankton Res., 18, 2223-2249, 1996.

Ahn, Y. H.: Proprietes optiques des particules biologiques et minerales presentes dans locean; Application: Inversion de la reflectance [Optical properties of biogenous and numerical particles in the ocean: application: inversion of reflectance], Ph.D. thesis, Universite Pierre et Marie Curie, 1990.

Amend, J. P., Edwards, K. J., and Lyons, T. W.: Sulfur Biogeochemistry, Geological Society of America, Special Paper 379, 2004.

Babin, M., Morel, A., Fournier-Sicre, V., Fell, F., and Stramski, D.: Light scattering properties of marine particles in coastal and open ocean waters as related to the particle mass concentration, Limnol. Oceanogr., 48, 843-859, 2003.

Baker, E. T. and Lavelle, J. W.: The effect of particle size on the light attenuation coefficient of natural suspensions, J. Geophys. Res., 89, 8179-8203, 1984.

Balch, W. M., Holligan, P. M., Ackleson, S. G., and Voss, K. J.: Biological and optical properties of mesoscale coccolithophore blooms in the Gulf of Maine, Limnol. Oceanogr., 36, 629-643, 1991.

Ball, M. M., Shinn, E. A., and Stockman, K. W.: The geologic effects of Hurricane Donna in south Florida, J. Geol., 7, 583 597, 1967.

Bennett, R. H., Li, H., Lambert, D. N., Fisher, K. M., Walter, D. J., Hickox, C. E., Hulbert, M. H., Yamamoto, T., and Badiey, M.: In situ porosity and permeability of selected carbonate sediment: Great Bahama Bank. Part 1: measurements, Mar. Geotechnol., 9, 1-28, 1990.

Boss, E. and Zaneveld, J. R. V.: The effect of bottom substrate on inherent optical properties: Evidence of biogeochemical processes, Limnol. Oceanogr., 48, 346-354, 2003.

Boss, E., Twardowski, M. S., and Herring, S.: Shape of the particulate beam attenuation spectrum and its inversion to obtain the shape of the particulate size distribution, Appl. Optics, 40, 48854893, 2001.

Boss, S. K. and Neumann, A. C.: Physical versus chemical processes of whiting formation in the Bahamas, Carbonate Evaporite, 8, 135-148, 1993.

Broecker, W. S.: Wally's quest to understand the Ocean's $\mathrm{CaCO} 3$ cycle, Ann Rev. Mar. Sci., 1, 1-18, 2009.

Broecker, W. S. and Takahashi, T.: Calcium carbonate precipitation on the Bahama Banks, J. Geophys. Res., 71, 1575-1602, 1966.

Broecker, W. S., Sanyal, A., and Takahashi, T.: The origin of Bahamian whitings revisited, Geophys. Res. Lett., 27, 3759-3760, 2000.

Bustos-Serrano, H., Morse, J. W., and Millero, F. J.: The formation of whitings on the Little Bahama Bank, Mar. Chem., 113, 1-8, 2009.

Chami, M, Shybanov, E. B., Churilova, T. Y., Khomenko, G. A., Lee, M. E.-G., Martynov, O. V., Berseneva, G. A., and Korotaev, G. K.: Optical properties of the particles in the Crimea coastal waters (Black Sea), J. Geophys. Res., 110, C11020, doi:10.1029/2005JC003008, 2005.

Clavano, W. R., Boss, E., and Karp-Boss, L.: Inherent optical properties of non-spherical marine-like particles - from theory to observation, Oceanogr. Mar. Biol. - An Annual Review, 45, 1-38, 2007. 
Cloud, P. E. J.: Environment of calcium carbonate deposition west of Andros Island, Bahamas, US Geol. Surv. Prof. Pap. 350, 138 pp., 1962.

Dierssen, H. M., Smith, R. C., and Vernet, M.: Glacial meltwater dynamics in coastal waters west of the Antarctic Peninsula, P. Natl. Acad. Sci. USA, 99, 1790-1795, 2002.

Dierssen, H. M., Zimmerman, R. C., Leathers, R. A., Downes, T. V., and Davis, C. O.: Ocean colour remote sensing of seagrass and bathymetry in the Bahamas Banks by high resolution airborne imagery, Limnol. Oceanogr., 48(1, part 2), 456-463, 2003.

Dierssen, H. M., Ryan, J., Kudela, R., and Zimmerman, R. C.: Red and black tides: Quantitative analysis of water-leaving radiance and perceived colour for phytoplankton, coloured dissolved organic matter, and suspended sediments, Limnol. Oceanogr., 55, 2646-2659, 2006.

Gargett, A., Wells, J., Tejada-Martinez, A. E., and Grosch, C. E.: Langmuir supercells: A mechanism for sediment resuspension and transport in shallow seas, Science, 306, 1925-1927, 2004.

Gargett, A. E. and Wells, J. R.: Langmuir turbulence in shallow water. Part 1. Observations, J. Fluid Mech., 576, 27-61, 2007.

Gould, R. W., Arnone, R. A., and Sydor, M.: Absorption, scattering, and remote-sensing reflectance relationships in coastal waters: Testing a new inversion algorithm, J. Coastal Res., 17, 329-341, 2001.

Gordon, H. R.: Atmospheric correction of ocean colour imagery in the Earth Observing System era, J. Geophys. Res., 102, 17 081$17106,1997$.

$\mathrm{Hu}, \mathrm{X}$.: Seagrass-mediated carbonate dissolution and early diagenesis in Bahamas Bank sediments, Ph.D. thesis, Old Dominion University, 201 pp., 2007.

Kirk, J. T. O.: Relationship between nephelometric turbidity and scattering coefficients in certain Australian waters, Aust. J. Mar. Fresh. Res., 31, 1-12, 1980.

Kirk, J. T. O.: Light and Photosynthesis in Aquatic Ecosystems, Cambridge University Press, 2nd edn., 509 pp., 1994.

Langmuir, I.: Surface motion of water induced by wind, Science, 87, 119-123, 1938.

Li, M. and Garrett, C.: Mixed layer deepening due to Langmuir circulation, J. Phys. Oceanogr., 27, 121-132, 1997.

McKee, D. and Cunningham, A.: Evidence for wavelength dependence of the scattering phase function and its implication for modeling radiance transfer in shelf seas, Appl. Optics, 44, 126135, 2005.

Miller, R. L. and McKee, B. A.: Using MODIS Terra $250 \mathrm{~m}$ imagery to map concentrations of suspended matter in coastal waters, Remote Sens. Environ., 93, 259-266, 2005.

Miller, S. D., Haddock, S. H. D., Elvidget, C. D., and Lee, T. F.: Detection of a bioluminescent milky sea from space, P. Natl. Acad. Sci. USA, 102, 14 181-14 184, 2005.

Milliman, J. D., Freile, D., Steinen, R. P., and Wilber, R. J.: Great Bahama Bank aragonitic muds: mostly inorganically precipitated, mostly exported, J. Sediment. Petrol., 63, 589-595, 1993.

Mobley, C. D.: Estimation of remote sensing reflectance from above-surface measurements, Appl. Optics, 38, 7442-7455, 1999.

Monahan, E. C. and Lu, M.: Acoustically relevant bubble assemblages and their dependence on meteorological parameters, IEEE J. Oceanic Eng., 15, 340-349, (1990).
Morel, A. and Bricaud, A.: Theoretical results concerning the optics of phytoplankton, with special reference to remote sensing applications, in: Oceanography from Space, Plenum Press, 313-327, 1981.

Morel, A. and Maritorena, S.: Bio-optical properties of oceanic waters: A reappraisal, J. Geophys. Res., 106, 7163-7180, 2001.

Morse, J. W.: Formation and diagenesis of carbonate sediments, in: Treatise on Geochemistry, edited by: Mackenzie, F. T., Elsevier, 7, 67-85, 2003.

Morse, J. W., Gledhill, D. K., and Millero, F. J.: CaCO3 precipitation kinetics in waters from the Great Bahama Bank: Implications for the relationship between Bank hydrochemistry and whitings, Geochim. Cosmochim. Ac., 67, 2819-2826, 2003.

Ohlendorf, C. and Sturm, M.: Precipitation and dissolution of calcite in a Swiss high alpine lake, Arct. Antarct. Alp. Res., 33, 410-417, 2001.

Otis, D. B., Carder, K. L., English, D. C., and Ivey, J. E.: CDOM transport from the Bahamas Banks, Coral Reefs, 23, 152-160, 2004.

Purdy, E. G.: Recent calcium carbonate facies of the Great Bahama Bank: 2. Sedimentary facies, J. Geol., 71, 472-497, 1963.

Robbins, L. L., Tau, Y., and Evans, C. A.: Temporal and spatial distribution of whitings on the Great Bahama Bank and a new lime mud budget, Geology, 25, 947-950, 1997.

Robbins, L. L. and Blackwelder, P. L.: Biochemical and ultrastructural evidence for the origin of whitings: A biologically induced calcium carbonate precipitation mechanism, Geology, 20, 464468, 1992.

Scheffer, M., Portielje, R., and Zambrano, L.: Fish facilitate wave resuspension of sediment, Limnol. Oceanogr., 48, 1920-1926, 2003.

Seibel, B. A. and Fabry, V. J.: Marine Biotic Response to Elevated Carbon Dioxide, Advances in Applied Biodiversity Science, 4, 59-67, 2003.

Shinn, E. A., Steinen, R. P., Lidz, B. H., and Swart, P. K.: Whitings, a sedimentologic dilemma, J. Sediment. Petrol., 59, 147-161, 1989.

Shinn, E. A., Steinen, R. P., Dill, R. F., and Major, R.: Lime-mud layers in high-energy tidal channels: A record of hurricane deposition, Geology, 21, 603-606, 1993.

Slade, W. and Boss, E.: Significance of particle aggregation on their optical properties, Proceedings of Ocean Optics XIX, Il Ciocco, Italy, CDROM, Office of Naval Research, 6-10 October 2008.

Smith, C. L.: The great Bahama Bank, 1, General hydrographical and chemical features, Calcium carbonate precipitation, J. Mar. Res., 3, 171-189, 1940.

Stramski, D., Boss, E., Bogucki, D., and Voss, K. J.: The role of seawater constituents in light backscattering in the ocean, Prog. Oceanogr., 61, 27-56, 2004.

Stramski, D., Babin, M., and Wozniak, S. B.: Variations in the optical properties of terrigenous mineral-rich particulate matter suspended in seawater, Limnol. Oceanogr., 52, 2418-2433, 2007.

Sullivan, J. M., Twardowski, M. S., Donaghay, P. L., and Freeman, S. A.: Use of optical scattering to discriminate particle types in coastal waters, Appl. Optics, 44, 1667-1680, 2005.

Tau, Y.: Whitings on the Great Bahama Bank: Distributions in space and time using Space Shuttle photographs, Master thesis, University of South Florida, Tampa, 77 pp., 1994. 
Tejada-Martinez, A. E. and Grosch, C. E.: Langmuir turbulence in shallow water. Part 2. Largeeddy simulation, J. Fluid Mech., 576, 63-108, 2007.

Thorpe, S.: Langmuir circulation, Annu. Rev. Fluid Mech., 36, 5579, 2004.

Twardowski, M. S., Boss, E., Macdonald, J. B., Pegau, W. S., Barnard, A. H., and Zaneveld, J. R. V.: A model for estimating bulk refractive index from the optical backscattering ratio and the implications for understanding particle composition in case I and case II waters, J. Geophys. Res., 105, 14 129-14 142, 2001.

Ulloa, O., Sathyendranath, S., and Platt, T.: Effect of the particlesize distribution on the backscattering ratio in seawater, Appl. Optics, 33, 7070-7077, 1994.
Whitmire, A. L., Boss, E., Cowles, T. J., and Pegau, W. S.: Spectral variability of the particulate backscattering ratio, Opt. Express, 15, 7019-7031, 2007.

Wilber. J. R., Milliman, J. D., and Halley, R. B.: Accumulation of bank-top sediment on the western slope of Great Bahama Bank: Rapid progradation of a carbonate megabank, Geology, 18, 970974, 1990.

Zaneveld, J. R. V., Kitchen, J. C., and Moore, C. C.: Scattering error correction of reflecting-tube absorption meters, in: Proc. Ocean Optics XII, edited by: Jaffe, S. J., SPIE Vol. 2258 Ocean Optics XII 2258, 44-55, 1994. 